\title{
GSTMI polymorphism is related to risks of nasopharyngeal cancer and laryngeal cancer: a meta-analysis
}

REVIEW

This article was published in the following Dove Press journal:

OncoTargets and Therapy

6 March 2017

Number of times this article has been viewed

\author{
Fengying Zhang ${ }^{1, *}$ \\ Xijiang $\mathrm{Wu}^{2, *}$ \\ Jinming $\mathrm{Niu}^{\prime}$ \\ Xiufeng Kang ${ }^{3}$ \\ Liya Cheng' \\ Yanchun Lv' \\ Meimei $\mathrm{Wu}^{\prime}$
}

'Otorhinolaryngological Department, Wei Fang Traditional Chinese Hospital, Weifang, Shandong Province, China; ${ }^{2}$ Otorhinolaryngological Department, Shouguang Peoples Hospital, Shouguang, Shandong Province, China; ${ }^{3}$ Medical insurance office, Shouguang Peoples Hospital, Shouguang, Shandong Province, China

*These authors contributed equally to this work
Correspondence: Fengying Zhang Otorhinolaryngological Department, Wei Fang Traditional Chinese Hospital, 1055 Weizhou Road, Kuiwen District. Weifang 261000, Shandong Province, China

Tel +865368060215

Emailym00223@I26.com
Background: Accumulating data have reported that GSTM1 polymorphism may be related to nasopharyngeal cancer (NPC) and laryngeal cancer (LC). This meta-analysis was performed to investigate the relationship between GSTM1 polymorphism and risks of NPC and LC.

Methods: Pubmed, Embase, and China National Knowledge Infrastructure (CNKI) databases were searched for potential articles. Odds ratios (ORs) and 95\% confidence intervals (CIs) were used to evaluate the relationship of GSTM1 polymorphism with the risks of NPC and LC. $P>50 \%$ or $P<0.05$ indicates significant heterogeneity. When heterogeneity existed, the random-effects model was used to pool data, otherwise, the fixed-effects model was adopted. Publication bias was detected by Begg's funnel plot and Egger's regression. Quality of each study was evaluated by Newcastle-Ottawa Scale.

Results: Thirty-two eligible articles were included. Pooled outcome suggested the significant relationship of GSTM1 null genotype with increased risk of $\mathrm{LC}(\mathrm{OR}=1.28,95 \% \mathrm{CI}=1.05-1.54)$. Compared with hospital-based (HB) population, GSTM1 null genotype was also related to increased risk of $\mathrm{LC}(\mathrm{OR}=1.38,95 \% \mathrm{CI}=1.06-1.80)$. Positive relationship of GSTM1 null genotype with enhanced risk of NPC was observed ( $\mathrm{OR}=1.43,95 \% \mathrm{CI}=1.26-1.63$ ). A similar trend was also observed in the subgroup analysis by source of control (population-based [PB]: $\mathrm{OR}=1.39,95 \% \mathrm{CI}=1.18-1.63 ; \mathrm{HB}: \mathrm{OR}=1.52,95 \% \mathrm{CI}=1.22-1.89)$.

Conclusion: GSTM1 null genotype is related to increased risk of NPC and LC.

Keywords: GSTM1, polymorphism, NPC, LC

\section{Introduction}

Nasopharyngeal cancer (NPC) is a fast-growing tumor which features distant metastasis and frequent nodal at diagnosis time. ${ }^{1}$ Epstein-Barr virus (EBV) infection has been demonstrated as a major risk factor for NPC. ${ }^{2}$ Besides, alcohol consumption and cigarette smoking could also increase the risk of NPC. ${ }^{3}$ Laryngeal cancer (LC) is a common malignancy in the head and neck region. ${ }^{4}$ Evidences have indicated that cigarette smoking and alcohol consumption play important roles in the development of the cancer. ${ }^{5}$ Recent studies indicate that carcinogen-metabolizing genes could modulate individual susceptibility to cancers. Polymorphisms of these genes may influence carcinogen activation/detoxification by altering the expression and function of the genes.

Xenobiotics could be detoxified by the GSTM1 and GSTT1 enzymes. These phase II enzymes are involved in the detoxification of benzopyrene and polycyclic aromatic hydrocarbons (PAHs). ${ }^{6}$ In addition, GSTM1 and GSTT1 serve as important factors in metabolizing carcinogens derived from tobacco smoke. ${ }^{7}$ It has been observed 
that homozygous deletions of GSTM1 and GSTT1 genes bring about phenotypic absence of glutathione S-transferases (GSTs) activity. ${ }^{89}$ GSTM1 and GSTT1 null genotypes show an association with susceptibility to lung cancer or bladder cancer, which are induced by environmental factors. ${ }^{10,11}$

GSTM1 products are responsible for catalyzing the conjugation of glutathione to epoxide derivatives of PAHs, which are the major carcinogens in tobacco smoke. ${ }^{12}$ Three different polymorphisms are observed in GSTM1 gene. ${ }^{13}$ Among them, the most important polymorphism (GSTM1 null genotype) causes the inactivation of GSTM1 enzyme. The frequency of the null genotype ranges from $23 \%$ to $62 \%$ among different populations. ${ }^{14}$

This present meta-analysis aimed to investigate the association of GSTM1 polymorphism with NPC and LC. The obtained outcome contributes to uncovering the pathogenesis of the cancers. Meanwhile, it contributes to clinical diagnosis of high-risk individuals for NPC and LC.

\section{Methods}

\section{Article search}

Pubmed, Embase, and China National Knowledge Infrastructure (CNKI) databases were searched for potential articles without language limitation. The search date was limited to May 2017. The keywords used in the search were: GSTM1, polymorphism or mutation or variant, nasopharyngeal carcinoma or nasopharynx cancer, LC or laryngocarcinoma. The references of obtained articles were also checked for additional articles.

\section{Inclusion and exclusion criteria}

The eligible articles had to meet the following criteria: (1) case-control studies; (2) articles investigating the relationship of GSTM1 polymorphism with NPC or LC; (3) articles providing the genotype data in case and control groups. The articles would be excluded if they were: (1) review articles; (2) animal or in vitro experiments; (3) GSTM1 polymorphism and risk of other cancers rather than NPC or LC.

\section{Data extraction}

Two authors were responsible for data extraction. The work was performed independently and any disagreements were resolved by discussion with a third author. The extracted information included: name of first author, publication year, country, ethnicity, experimental method, sample size, and genotypes' distribution in case and control groups. Quality of each study was evaluated by the method of NewcastleOttawa Scale (NOS).

\section{Statistical analysis}

All the analyses were performed with Stata 12.0 software. Odds ratios (ORs) with $95 \%$ confidence intervals (CIs) were calculated to evaluate the relationship of GSTM1 polymorphism with NPC or LC. $I^{2}$ and $P$-value were used to assess the inter-study heterogeneity. $I^{2}>50 \%$ or $P<0.05$ indicates the presence of heterogeneity. If heterogeneity existed, the random-effects model was performed to pool data, otherwise, the fixed-effects model was used. Subgroup analyses based on ethnicity and source of control were initiated as well. Sensitivity analysis was conducted to assess the robustness of pooled results. Begg's funnel plot and Egger's regression analysis were used to evaluate the potential publication bias.

\section{Results}

\section{Article selection}

During the search, a total of 346 relevant articles were obtained. After screening the titles and abstracts, 213 records were excluded for review articles ( $\mathrm{n}=82$ ), GSTM1 polymorphism and other cancers $(\mathrm{n}=67)$, and other genes and NPC or LC $(n=64)$. The remaining 133 articles were evaluated for eligibility. During the evaluation, 101 articles were excluded for unavailable data $(n=35)$, case studies $(n=37)$, GSTM1 polymorphism and pathological condition $(n=29)$. Finally, 32 eligible articles were selected for the present meta-analysis. ${ }^{15-46}$ The detailed selection process was shown in Figure 1. The basic information of included articles was listed in Table 1 . The results about the quality assessment was shown in Table 1 as well.

\section{Relationship of GSTMI polymorphism with LC}

Random-effects model was used to analyze the association between GSTM1 polymorphism and risk of LC $(P=0.000)$. The pooled results indicated that GSTM1 null genotype was related to increased risk of LC (OR $=1.28,95 \%$ $\mathrm{CI}=1.05-1.54)$. Subgroup analyses by ethnicity and source of control were performed as well (Table 2). The outcome indicated that GSTM1 null genotype was correlated with enhanced risk of LC, compared with hospital-based (HB) population ( $\mathrm{OR}=1.38,95 \% \mathrm{CI}=1.06-1.80)$ (Figure 2). No positive results were observed in the analysis of ethnicity.

\section{Relationship of GSTMI polymorphism with NPC}

Fixed-effects model was adopted to analyze the relationship of GSTM1 polymorphism with NPC $(P=0.417)$. Overall results indicated that GSTM1 null genotype could increase the risk of NPC $(\mathrm{OR}=1.43,95 \% \mathrm{CI}=1.26-1.63)$. In the 


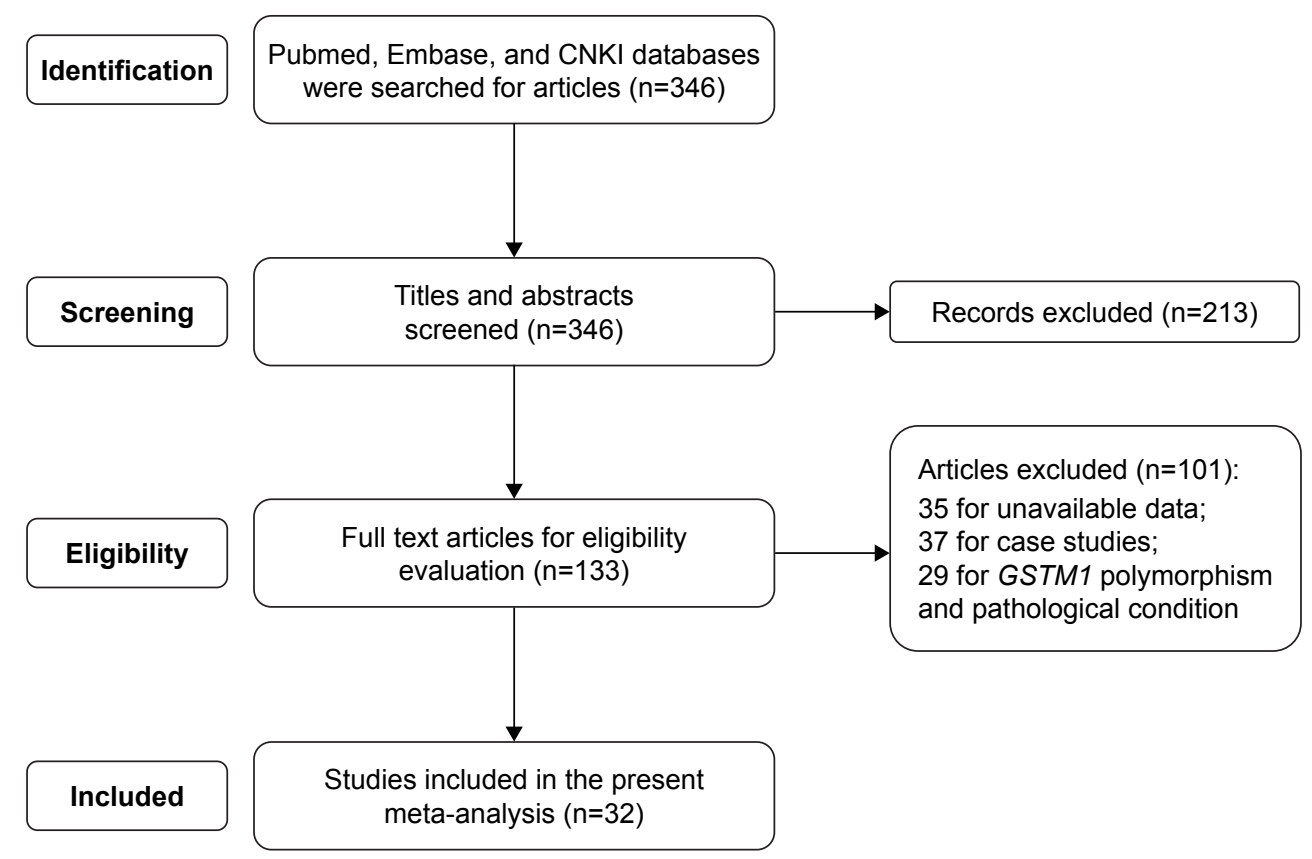

Figure I Article selection process. 32 eligible articles were included into the present meta-analysis. Abbreviation: CNKI, China National Knowledge Infrastructure.

Table I Basic information of included articles

\begin{tabular}{|c|c|c|c|c|c|c|c|c|c|}
\hline \multirow[t]{2}{*}{ Cancers } & \multirow[t]{2}{*}{ Author } & \multirow[t]{2}{*}{ Year } & \multirow[t]{2}{*}{ Country } & \multirow[t]{2}{*}{ Method } & \multirow[t]{2}{*}{ Score } & \multicolumn{2}{|l|}{ Case } & \multicolumn{2}{|l|}{ Control } \\
\hline & & & & & & Present & Null & Present & Null \\
\hline \multirow[t]{21}{*}{ LC } & Unal et al ${ }^{26}$ & 2004 & Turkey & Real-time PCR & 5 & 23 & 19 & 57 & 32 \\
\hline & Gajecka et $\mathrm{al}^{27}$ & 2005 & Poland & PCR-RFLP & 7 & 152 & 140 & 157 & 164 \\
\hline & Acar et $\mathrm{al}^{28}$ & 2006 & Turkey & PCR & 8 & 53 & 57 & 123 & 74 \\
\hline & To-Figueras et $\mathrm{al}^{29}$ & 2002 & Spain & PCR-RFLP & 8 & 108 & 96 & 103 & 100 \\
\hline & Hong et $\mathrm{al}^{30}$ & 2000 & Korean & PCR & 8 & 26 & 56 & 30 & 33 \\
\hline & Charzimichalis et $\mathrm{a}^{3 !}$ & 2010 & Greece & PCR & 8 & 14 & 74 & 14 & 88 \\
\hline & Jourenkova et $\mathrm{a}^{32}$ & 1998 & France & PCR & 9 & 51 & 78 & 82 & 90 \\
\hline & Tian et al ${ }^{33}$ & 2011 & China & PCR & 8 & 117 & 116 & 80 & 22 \\
\hline & Lourenco et $\mathrm{al}^{34}$ & 2011 & Brazil & PCR-RFLP & 7 & 23 & 14 & 76 & 66 \\
\hline & Yan and Zhou ${ }^{35}$ & 2003 & China & PCR & 7 & 12 & 30 & 56 & 52 \\
\hline & $\mathrm{Li}$ et $\mathrm{al}^{36}$ & 2004 & China & PCR & 7 & 39 & 50 & 95 & 69 \\
\hline & Morita et $\mathrm{al}^{37}$ & 1999 & Japan & PCR & 7 & 39 & 81 & 30 & 83 \\
\hline & Kihara et al ${ }^{38}$ & 1997 & Japan & PCR & 8 & 70 & 86 & 242 & 230 \\
\hline & Bardakci et $\mathrm{al}^{39}$ & 2003 & Turkey & PCR & 8 & 11 & 25 & 19 & 16 \\
\hline & Gattas et al ${ }^{40}$ & 2006 & Brazil & PCR-RFLP & 8 & 12 & 10 & 63 & 39 \\
\hline & Lei et $\mathrm{al}^{41}$ & 2003 & China & PCR & 7 & 17 & 45 & 28 & 28 \\
\hline & Matthias et al ${ }^{42}$ & 2003 & German & PCR & 7 & 114 & $|5|$ & 83 & 95 \\
\hline & Risch et $\mathrm{a}^{43}$ & 2003 & German & PCR-RFLP & 9 & 118 & 127 & 116 & 135 \\
\hline & Gronau et $\mathrm{al}^{44}$ & 2003 & German & PCR & 8 & 107 & 80 & 71 & 68 \\
\hline & Jahnke et $\mathrm{al}^{45}$ & 1997 & German & PCR-RFLP & 8 & 118 & 51 & 104 & 112 \\
\hline & Biselli et al ${ }^{46}$ & 2006 & Brazil & PCR & 8 & 15 & 7 & 31 & 29 \\
\hline \multirow[t]{11}{*}{ NPC } & Deng et $\mathrm{a}^{15}$ & 2004 & China & PCR & 7 & 35 & 56 & 71 & 64 \\
\hline & Jiang et $\mathrm{al}^{16}$ & 2011 & China & PCR & 7 & 85 & 97 & 215 & 157 \\
\hline & Cheng et $\mathrm{al}^{17}$ & 2003 & China & PCR & 8 & $|4|$ & 173 & 168 & 169 \\
\hline & Guo et al ${ }^{18}$ & 2008 & China & PCR & 8 & 137 & 204 & 262 & 328 \\
\hline & Zhang ${ }^{19}$ & 2012 & China & PCR-CTPP & 7 & 18 & 27 & 19 & II \\
\hline & Da et $\mathrm{al}^{20}$ & 2002 & China & PCR & 8 & 32 & 48 & 44 & 36 \\
\hline & Wei et $\mathrm{al}^{21}$ & 2010 & China & PCR & 7 & 48 & 48 & 336 & 305 \\
\hline & Deng et $\mathrm{a}^{22}$ & 2005 & China & PCR & 7 & 49 & 78 & 112 & 95 \\
\hline & Tiwawech et al ${ }^{23}$ & 2005 & Japan & PCR & 7 & 28 & 50 & 71 & 74 \\
\hline & Liao et $\mathrm{a}^{24}$ & 2005 & China & PCR & 7 & 30 & 50 & 40 & 32 \\
\hline & Nazar-Stewart et a ${ }^{25}$ & 1999 & America & PCR & 8 & 38 & 45 & 79 & 63 \\
\hline
\end{tabular}

Note: Quality assessment of each study was performed by the method of Newcastle-Ottawa Scale and the score was calculated.

Abbreviations: PCR, polymerase chain reaction; PCR-RFLP, polymerase chain reaction-restriction fragment length polymorphism; PCR-CTPP, polymerase chain-reaction with the confronting-two-pair primer; NPC, nasopharyngeal cancer; LC, laryngeal cancer. 
Table 2 Pooled results of the present meta-analysis

\begin{tabular}{llllll}
\hline Cancers & Subgroup & Types & OR & $\mathbf{9 5 \%} \mathbf{C l}$ & $\begin{array}{l}\text { P-value for } \\
\text { heterogeneity }\end{array}$ \\
\hline LC & Ethnicity & Caucasian & 1.27 & $0.99-1.56$ & 0.000 \\
& & Asian & 1.36 & $0.96-1.93$ & 0.053 \\
& Source of & PB & 1.13 & $0.86-1.48$ & 0.022 \\
& control & HB & 1.38 & $1.06-1.80$ & 0.000 \\
\multirow{4}{*}{ NPC } & Total & - & 1.28 & $1.05-1.54$ & 0.000 \\
& Source of & PB & 1.39 & $1.18-1.63$ & 0.309 \\
& control & HB & 1.52 & $1.22-1.89$ & 0.423 \\
& Total & - & 1.43 & $1.26-1.63$ & 0.417 \\
\hline
\end{tabular}

Abbreviations: LC, laryngeal cancer; NPC, nasopharyngeal cancer; OR, odds ratio; $\mathrm{Cl}$, confidence interval; $\mathrm{PB}$, population-based; $\mathrm{HB}$, hospital-based.

subgroup analysis by source of control, we found that GSTM1 null genotype was still related to increased risk of NPC (population-based: $\mathrm{OR}=1.39,95 \% \mathrm{CI}=1.18-1.63$; $\mathrm{HB}$ : $\mathrm{OR}=1.52,95 \% \mathrm{CI}=1.22-1.89$ ) (Figure 3).

\section{Sensitivity analysis}

Sensitivity analysis was performed by deleting one study at a time. The analysis indicated that the pooled results were robust.

\section{Publication bias detection}

Begg's funnel plot and Egger's regression analysis were performed to detect the potential publication bias. The funnel plot seemed to be symmetrical ( $P=0.436$ ) (Figure 4$)$. Egger's analysis also suggested the absence of publication bias $(P=0.097)$.

\section{Discussion}

GSTs, member of a super-family of detoxification enzymes, show important effects in resisting various environmental toxicants and chemical carcinogens. For the phase II detoxification enzymes, more than five classes (mu, sigma, pi, alpha, theta) of GSTs have been confirmed. Among these enzymes, only enzymes of GST-M (mu), GST-T (theta) and GST-P (pi) play important roles in the detoxification of carcinogenic electrophiles. Null mutations of GSTM1 are linked with complete loss of enzyme activities for binding with genotoxic substrates, such as epoxides. ${ }^{47}$ Cumulative data have confirmed that individuals with null genotype of GSTM1 are more likely to develop various cancers such as colorectal cancer, prostate cancer, gastric cancer, lung cancer,

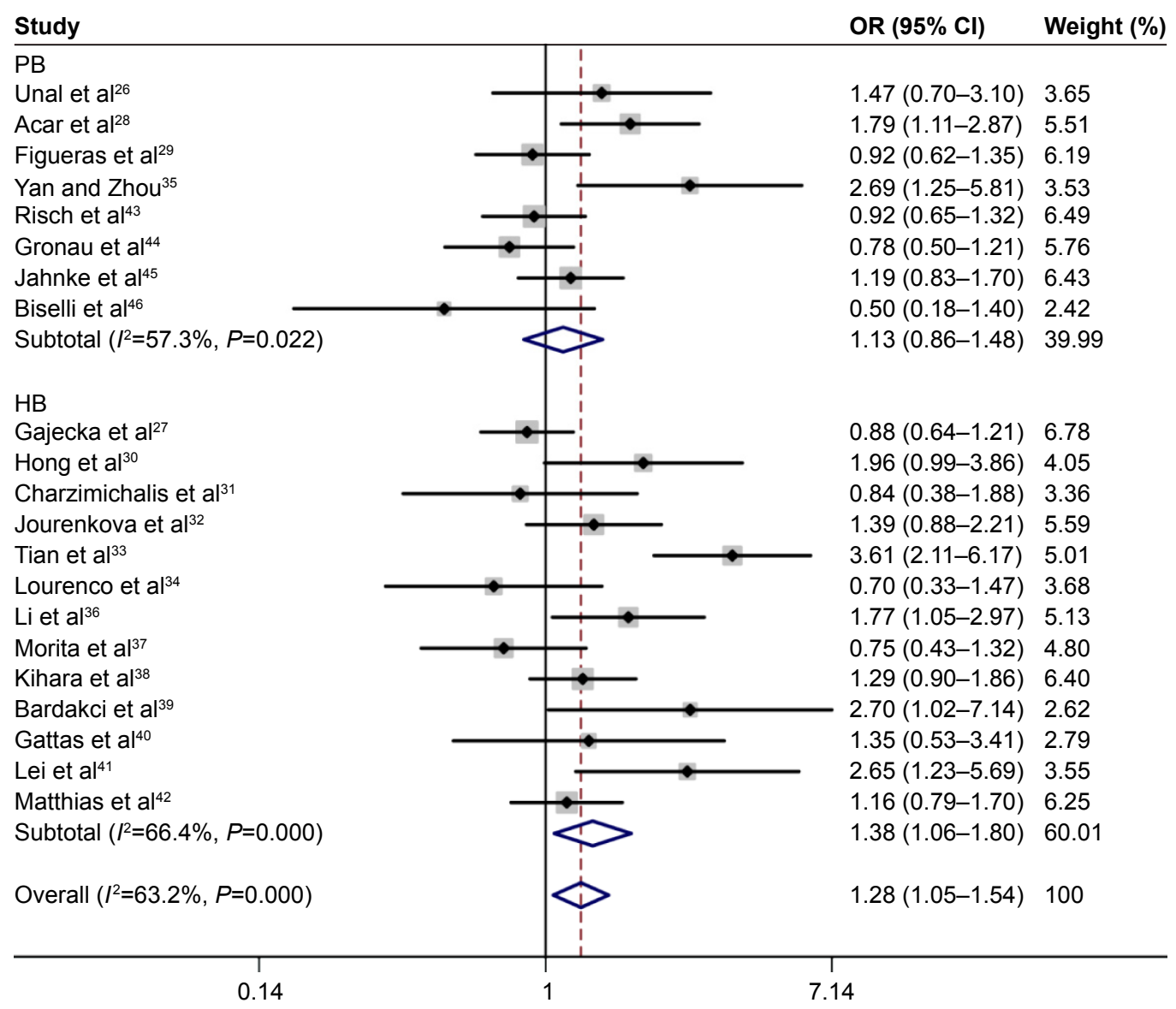

Figure 2 Subgroup analysis by source of control about the association between GSTMI null genotype and risk of LC. Note: Weights are from random effects analysis.

Abbreviations: LC, laryngeal cancer; OR, odds ratio; Cl, confidence interval; PB, population-based; HB, hospital-based. 


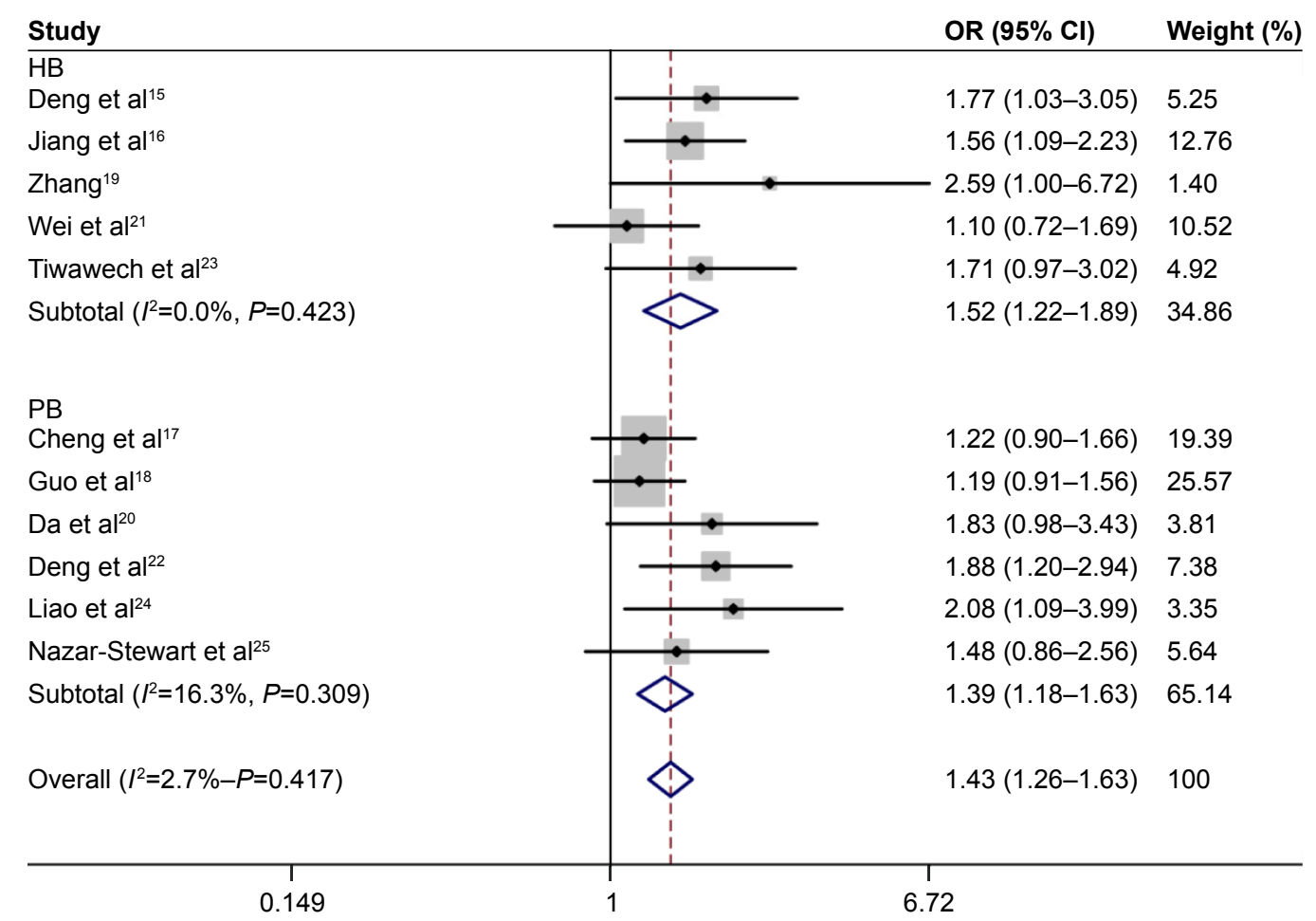

Figure 3 Subgroup analysis by source of control about the association between GSTMI null genotype and risk of NPC.

Abbreviations: NPC, nasopharyngeal cancer; OR, odds ratio; $\mathrm{Cl}$, confidence interval; PB, population-based; HB, hospital-based.

liver cancer, bladder cancer, breast cancer, ovarian cancer, skin cancer, oral cancer, NPC, and LC..$^{25,27,48-57}$

Accumulating data suggest that EBV infection, carcinogen exposure, and genetic susceptibility play an important role in NPC tumorigenesis. EBV infection is confirmed as a causal factor. ${ }^{58}$ However, not all EBV-infected individuals would develop NPC, which indicates that other factors may be involved in the pathogenesis of the cancer, such as tumor promotion, lifestyle, and exposure to carcinogens. ${ }^{59-61}$ Besides, susceptibility genes such as interferon-alpha, HLA-regions and p53 alleles, and certain polymorphic genes encoding

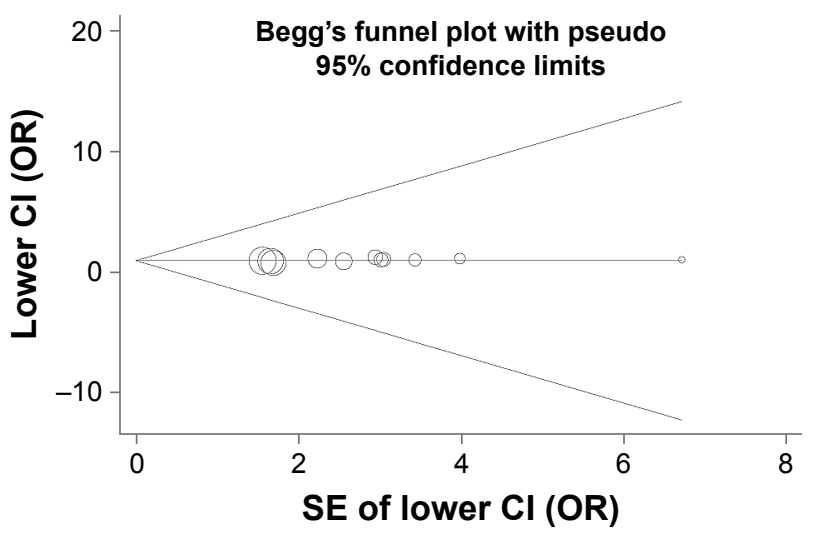

Figure 4 Begg's funnel plot (NPC). The funnel plot seemed to be symmetrical $(P=0.436)$.

Abbreviations: NPC, nasopharyngeal cancer; OR, odds ratio; $\mathrm{Cl}$, confidence interval; SE, standard error. enzymes involved in metabolic activation and detoxification of xenobiotics have been regarded as risk factors. ${ }^{62,63}$ The null genotype of GSTM1 is linked with the loss of enzyme activity for binding with genotoxic substrates, therefore, the individuals with GSTM1 null are believed to be more likely to suffer NPC than individuals with normal genotype of GSTM1. The fact is that frequency of GSTM1 null genotype is different among different ethnic groups, such as 45\%-56\% in Asians, 40\%-58\% in Caucasians, and 29\%-30\% in AfricanAmericans. ${ }^{64-67}$ In addition, the opinions on the relationship of GSTM1 null genotype with risk of NPC were inconsistent among the published studies. Therefore, this meta-analysis was initiated to obtain a more accurate outcome. The outcome indicated that GSTM1 null genotype could increase the risk of $\mathrm{NPC}(\mathrm{OR}=1.43,95 \% \mathrm{CI}=1.26-1.63)$. A similar outcome was also observed in the subgroup analysis by source of control.

As for LC, smoking tobacco has been regarded as its main risk factor and only $1 \%$ of LC occurs among nonsmokers. However, not all smokers would develop LC. The incidence of LC is different among different countries and ethnic groups. Besides, LC cases exhibit geographic variations in distribution. These evidences indicate the important role of genetic susceptibility in the pathogenesis of LC. Tobacco contains aldehydes, nitrosamines, aromatic amines, and PAHs. These components can cause genetic mutations. There are many protective enzymes functioning in the deactivation or degradation of 
carcinogenic compounds, such as phase I enzymes (cytochrome p450, alcohol dehydrogenase) and phase II enzymes (N-acetyl transferases, GSTs). These enzymes, known as xenobiotic-metabolizing enzymes, commonly exist in the liver and have been found in the mucosa of the upper aerodigestive tract. ${ }^{68}$ Phase II enzymes are involved in most metabolic detoxification processes of chemical carcinogens. Products of GSTM1 gene contribute to conjugating glutathione to epoxide derivatives of PAHs. The associations of GSTM1 null genotypes with tobacco-related cancers have been extensively reported, however, the role of GSTM1 polymorphism in LC is still controversial. Our results, based on a meta-analysis, suggested that GSTM1 null genotype was related to increased risk of $\mathrm{LC}(\mathrm{OR}=1.28,95 \% \mathrm{CI}=1.05-1.54)$. The subgroup analysis by source of control also indicated that GSTM1 null genotype was correlated with enhanced risk of LC.

This meta-analysis was performed with 32 eligible articles. The sample size was 10,185. The outcome showed certain priority in accuracy compared with other studies. However, several limitations existed in the analysis. Only GSTM1 genetic polymorphism was analyzed, phase I and other phase II enzymes were not considered. Future analysis should focus much more on genes encoding these enzymes, which will contribute to uncovering the pathogenesis of NPC and LC. In addition, the occurrences of NPC and LC involve many risk factors. The analysis only considered the genetic factor and other environmental factors and genes should be investigated to get a much more complete outcome. Besides, significant heterogeneity existed in the analysis of LC, which might affect the accuracy of pooled results.

Subgroup analyses based on ethnicity and source of control were performed to identify the source of heterogeneity.

\section{Conclusion}

GSTM1 null genotype was related to increased risk of NPC and LC. The outcome will contribute to screening high-risk populations for NPC and LC.

\section{Acknowledgment}

We are indebted to the authors of the primary studies.

\section{Disclosure}

The authors report no conflicts of interest in this work.

\section{References}

1. Lin CL, Lo WF, Lee TH, et al. Immunization with Epstein-Barr Virus (EBV) peptide-pulsed dendritic cells induces functional CD8+ T-cell immunity and may lead to tumor regression in patients with EBV-positive nasopharyngeal carcinoma. Cancer Res. 2002;62(23):6952-6958.
2. O'Neil JD, Owen TJ, Wood VH, et al. Epstein-Barr virus-encoded EBNA1 modulates the AP-1 transcription factor pathway in nasopharyngeal carcinoma cells and enhances angiogenesis in vitro. $J$ Gen Virol. 2008;89(Pt 11):2833-2842.

3. Cheng YJ, Hildesheim A, Hsu MM, et al. Cigarette smoking, alcohol consumption and risk of nasopharyngeal carcinoma in Taiwan. Cancer Causes Control. 1999;10(3):201-207.

4. Cann CI, Fried MP, Rothman KJ. Epidemiology of squamous cell cancer of the head and neck. Otolaryngol Clin North Am. 1985;18(3): 367-388.

5. Koskinen WJ, Brøndbo K, Mellin Dahlstrand H, et al. Alcohol, smoking and human papilloma-virus in laryngeal carcinoma: a Nordic prospective multicenter study. J Cancer Res Clin Oncol. 2007; 133(9):673-678.

6. Schneider J, Bernges U, Philipp M, Woitowitz HJ. GSTM1, GSTT1, and GSTP1 polymorphism and lung cancer risk in relation to tobacco smoking. Cancer Lett. 2004;208(1):65-74.

7. Rebbeck TR. Molecular epidemiology of the human glutathione S-transferase genotypes GSTM1 and GSTT1 in cancer susceptibility. Cancer Epidemiol Biomarkers Prev. 1997;6(9):733-743.

8. Seidegard J, Vorachek WR, Pero RW, Pearson WR. Hereditary difference in the expression of the human glutathione transferase active on trans-stilbene oxide are due to a gene deletion. Proc Natl Acad Sci US A. 1988;85(19):7293-7297.

9. Pemble S, Schroeder KR, Spencer SR, et al. Human glutathione S-transferase $\theta$ (GSTT1): cDNA cloning and the characterization of genetic polymorphism. Biochem J. 1994;300(Pt 1):271-276.

10. Saarikoski ST, Voho A, Reinikainen M, et al. Combined effect of polymorphic GST genes on individual susceptibility to lung cancer. Int J Cancer. 1998;77(4):516-521.

11. Bell DA, Taylor JA, Paulson DF, et al. Genetic risk and carcinogen exposure: a common inherited defect of the carcinogen-metabolism gene glutathione S-transferase M1 (GSTM1) that increases susceptibility to bladder cancer. J Natl Cancer Inst. 1993;85(14):1159-1164.

12. Hanna E, MacLeod S, Vural E, Lang N. Genetic deletions of glutathioneS-transferase as a risk factor in squamous cell carcinoma of the larynx: A preliminary report. Am J Otolaryngol. 2001;22(2):121-123.

13. Beckett GJ, Hayes JD. Glutathione S-transferases: biomedical applications. Adv Clin Chem. 1993;30:281-380.

14. Cotton SC, Sharp L, Little J, Brockton N. Glutathione S-transferase polymorphisms and colorectal cancer: A HuGe review. Am J Epidemiol. 2000;151(1):7-32.

15. Deng ZL, Wei YP, Ma Y. [Frequent genetic deletion of detoxifying enzyme GSTM1 and GSTT1 genes in nasopharyngeal carcinoma patients in Guangxi Province, China]. Zhonghua Zhong Liu Za Zhi. 2004;26(10):598-600. Chinese.

16. Jiang Y, Li N, Dong P, et al. Polymorphisms in GSTM1, GSTT1 and GSTP1 and nasopharyngeal cancer in the east of China: a case-control study. Asian Pac J Cancer Prev. 2011;12(11):3097-3100.

17. Cheng YJ, Chien YC, Hildesheim A, et al. No association between genetic polymorphisms of CYP1A1, GSTM1, GSTT1, GSTP1, NAT2, and nasopharyngeal carcinoma in Taiwan. Cancer Epidemiol Biomarkers Prev. 2003;12(2):179-180.

18. Guo XC, O’Brien SJ, Zeng Y, Nelson GW, Winkler CA. GSTM1 and GSTT1 gene deletions and the risk for nasopharyngeal carcinoma in Han Chinese. Cancer Epidemiol Biomarkers Prev. 2008;17(7): 1760-1763.

19. Zhang G. CYP1A1 及 GSTM1 基因多态性与鼻咽癌发病风险关系的 研究. [To investigate the relationship between CYP1A1 and GSTM1 gene polymorphisms and nasopharyngeal carcinoma (thesis)]. Dali: Dali University, People's Republic of China; 2012. China.

20. Da SJ, Liang B, Wu HL, Guan LL. GSTM1 基因多态性与鼻咽癌遗传 易感性的关系研究 [Relationship between GSTM1 gene polymorphism and genetic susceptibility in nasopharyngeal carcinoma]. The Practical Journal of Cancer. 2002;17(6):617-618, 626. Chinese. 
21. Wei YP, Long XD, Liu ZG, Ma Y, Deng ZL. 肝细胞癌、鼻咽癌患 者谷胱甘肽硫转移酶 $\mathrm{M} 1$ 和 $\mathrm{T} 1$ 基因型分布 [Genetic polymorphism of Glutathione-S-transferase M1 and T1 in hepatocellular carcinoma and nasopharyngeal carcinoma]. Cancer Research on Prevention and Treatment. 2010;37(10):1162-1165. Chinese.

22. Deng ZL, Wei YP, Luo W, Liao ZL, Ma Y. Glutathione S-transferase $\mathrm{M} 1$ and $\mathrm{T} 1$ gene deletion associated with increased susceptibility to nasopharyngeal carcinoma. The Chinese-German Journal of Clinical Oncology. 2005;4(5):276-278.

23. Tiwawech, Srivatanakul P, Karalak A, Ishida T. Glutathione S-transferase M1 gene polymorphism in Thai nasopharyngeal carcinoma. Asian Pac J Cancer Prev. 2005;6(3):270-275.

24. Liao Z, Deng ZL, Wei YP, et al. GSTT1, GSTM1基因缺失多态性 与鼻咽癌的发病关系 [Relationships of GSTT1, GSTM1 deletion polymorphisms with risk of nasopharyngeal carcinoma]. Journal of Guangxi Medical University. 2005;22(3):372-374. Chinese.

25. Nazar-Stewart V, Vaughan TL, Burt RD, Chen C, Berwick M, Swanson GM. Glutathione S-Transferase M1 and susceptibility to nasopharyngeal carcinoma. Cancer Epidemiol Biomarkers Prev. 1999;8(6) $547-551$.

26. Unal M, Tamer L, Ates NA, et al. Glutathione S-transferase M1, T1, and $\mathrm{P} 1$ gene polymorphism in laryngeal squamous cell carcinoma. $\mathrm{Am}$ J Otolaryngol. 2004;25(5):318-322.

27. Gajecka M, Rydzanicz M, Jaskula-Sztul R, Kujawski M, Szyfter W, Szyfter K. CYP1A1, CYP2D6, CYP2E1, NAT2, GSTM1 and GSTT1 polymorphisms or their combinations are associated with the increased risk of the laryngeal squamous cell carcinoma. Mutat Res. 2005;574(1-2):112-123.

28. Acar H, Ozturk K, Muslumanoglu MH, et al. Relation of glutathione S-transferase genotypes (GSTM1 and GSTT1) to laryngeal squamous cell carcinoma risk. Cancer Genet Cytogenet. 2006;169(2):89-93.

29. To-Figueras J, Gene M, Gomez-Catalan J, et al. Microsomal epoxide hydrolase and glutathione S-transferase polymorphisms in relation to laryngeal carcinoma risk. Cancer Lett. 2005;187(1-2):95-101.

30. Hong YJ, Lee JK, Lee GH, Hong SI. Influence of Glutathione S-transferase M1 and T1 genotypes on larynx cancer risk among Korean smokers. Clin Chem Lab Med. 2000;38(9):917-919.

31. Charzimichalis M, Xenellis J, Tzagaroulakis A, et al. GSTT1, GSTM1, GSTM3 and NAT2 polymorphisms in laryngeal squamous cell carcinoma in a Greek population. $J$ Laryngol Otol. 2010;124(3):318-323.

32. Jourenkova N, Reinikainen M, Bouchardy C, Dayer P, Benhamous S, Hirvonen A. Larynx cancer risk in relation to glutathione S-transferase M1 and T1 genotypes and tobacco smoking. Cancer Epidemiol Biomarkers Prev. 1998;7(1):19-23.

33. Tian SZ, Zhang JG, Xiao Q, et al. [The association between genetic polymorphisms of GSTM1, GSTT1, GSTP1 and susceptibility to laryngeal carcinoma from the Han people in Guangdong zone]. Lin Chung Er Bi Yan Hou Tou Jing Wai Ke Za Zhi. 2011;25(5):204-210. Chinese.

34. Lourenco GJ, Silva EF, Rinck-Junior JA, Chone CT, Lima CS. CYP1A1, GSTM1 and GSTT1 polymorphisms, tobacco and alcohol status and risk of head and neck squamous cell carcinoma. Tumour Biol. 2011;32(6):1209-1215.

35. Yan YB, Zhou WR. 谷胱甘肽 $\mathrm{S}$ 转移酶M1基因缺失与喉癌易患性 的相关性研究 [Glutathinoe S-transferase M1 null genotypes and susceptibility to laryngeal carcinoma]. Journal of Nantong University (Medical Sciences). 2003;23:255-257. Chinese.

36. Li L, Lin P, Deng YF, Zhu ZL, Lu HH. [Relationship between susceptibility and prognosis of laryngeal cancer and genetic polymorphisms in CYP1A1 and GSTM1]. Zhonghua Er Bi Yan Hou Ke Za Zhi. 2004;39(1):2-7. Chinese.

37. Morita S, Yano M, Tsujinaka T, et al. Genetic polymorphisms of drugmetabolizing enzymes and susceptibility to head-and-neck squamouscell carcinoma. Int J Cancer. 1999;80(5):685-688.

38. Kihara M, Kihara M, Kubota A, Furukawa M, Kimura H. GSTM1 gene polymorphism as a possible marker for susceptibility to head to neck cancers among Japanese smokers. Cancer Lett. 1997;112(2):257-262.
39. Bardakci F, Canbay E, Degerli N, Coban L, Canbay EI. Relationship of tobacco smoking with GSTM1 gene polymorphism in laryngeal cancer. J Cell Mol Med. 2003;7(3):307-312.

40. Gattas GJ, de Carvalho MB, Siraque MS, et al. Genetic polymorphisms of CYP1A1, CYP2E1, GSTM1, and GSTT1 associated with head and neck cancer. Head Neck. 2006;28(9):819-826.

41. Lei DP, Pan XL, Guo CH, et al. GSTM1空白基因型与喉癌遗传 易感性的研究 [The study about GSTM1 null genotype and genetic susceptibility of laryngeal cancer]. Chinese Journal of Medical Genetics. 2002;19:534-535. Chinese.

42. Matthias C, Bockmuhl U, Jahnke V, et al. Polymorphism in cytochrome P450 CYP2D6, CYP1A1, CYP2E1 and glutathione S-transferase, GSTM1, GSTM3, GSTT1 and susceptibility to tobacco-related cancers: studies in upper aerodigestive tract cancers. Pharmacogenetics.1998; 8(2):91-100.

43. Risch A, Ramroth H, Raedts V, et al. Laryngeal cancer risk in Caucasians is associated with alcohol and tobacco consumption but not modified by genetic polymorphisms in class I alcohol dehydrogenases $\mathrm{ADH} 1 \mathrm{~B}$ and ADH1C, and glutathione-S-transferases GSTM1 and GSTT1. Pharmacogenetics. 2003;13(4):225-230.

44. Gronau S, Koenig-Greger D, Jerg M, Riechelmann H. Gene polymorphisms in detoxification enzymes as susceptibility factor for head and neck cancer. Otolaryngol Head Neck Surg. 2003;128(5):674-680.

45. Jahnke V, Strange R, Matthias C, Fryer A. Glutathione S-transferase and cytochrome $\mathrm{P} 450$ genotypes as risk factors for laryngeal carcinoma. Eur Arch Otorhinolaryngol. 1997;253 Suppl 1:S147-S149.

46. Biselli JM, de Angelo Calsaverini Leal RC, Ruiz MT, et al. GSTT1 and GSTM1 polymorphism in cigarette smokers with head and neck squamous cell carcinoma. Braz J Otorhinolaryngol. 2006;72(5): 654-658.

47. Hayes JD, Pulford DJ. The glutathione S-transferase supergene family: regulation of GST and the contribution of the isoenzymes to cancer chemoprotection and drug resistance. Crit Rev Biochem Mol Biol. 1995;30(6):445-600.

48. Gawronska-Szklarz B, Lubinski J, Klandy J, et al. Polymorphism of GSTM1 gene in patients with colorectal cancer and colonic polyps. Exp Toxicol Pathol. 1999;51(4-5):321-325.

49. Autrup JL, Thomassen LH, Olsen JH, Wolf H, Autrup H. Glutathione S-transferases as risk factors in prostate cancer. Eur J Cancer Prev. 1999;8(6):525-532.

50. Setiawan VW, Zhang ZF, Yu GP, et al. GSTT1 and GSTM1 null genotypes and risk of gastric cancer: a case-control study in a Chinese population. Cancer Epidemiol Biomarkers Prev. 2000;9(1):73-80.

51. Sweeney C, Nazar-Stewart V, Stapleton PL, Eaton DL, Vaughan TL. Glutathione S-transferase M1, T1, and P1 polymorphisms and survival among lung cancer patients. Cancer Epidemiol Biomarkers Prev. 2003;12(6):527-533.

52. Deng ZL, Wei YP, Ma Y. Polymorphism of glutathione S-transferase $\mathrm{mu} 1$ and theta 1 genes and hepatocellular carcinoma in southern Guangxi, China. World J Gastroenterol. 2005;11(2):272-274.

53. Srivastava DS, Kumar A, Mittal B, Mittal RD. Polymorphism of GSTM1 and GSTT1 genes in bladder cancer: a study from North India. Arch Toxicol. 2004;78(8):430-434.

54. van der Hel OL, Peeters PH, Hein DW, et al. NAT2 slow acetylation and GSTM1 null genotypes may increase postmenopausal breast cancer risk in long-term smoking women. Pharmacogenetics. 2003;13(7):399-407.

55. Spurdle AB, Webb PM, Purdie DM, Chen X, Green A, ChenevixTrench G. Polymorphisms at the glutathione S-transferase GSTM1, GSTT1 and GSTP1 loci: risk of ovarian cancer by histological subtype. Carcinogenesis. 2001;22(1):67-72.

56. Heagerty AH, Fitzgerald D, Smith A, et al. Glutathione S-transferase GSTM1 phenotypes and protection against cutaneous tumours. Lancet. 1994;343(8892):266-268.

57. Kietthubthew S, Sriplung H, Au WW. Genetic and environmental interactions on oral cancer in Southern Thailand. Environ Mol Mutagen. 2001;37(2):111-116. 
58. Zong YS, Sham JS, $\mathrm{Ng} \mathrm{MH}$, et al. Immunoglobulin A against viral capsid antigen of Epstein-Barr virus and indirect mirror examination of the nasopharynx in the detection of asymptomatic nasopharyngeal carcinoma. Cancer. 1992;69(1):3-7.

59. Mirabelli MC, Hoppin J, Tolbert PE, et al. Occupational exposure to chlorophenol and the risk of nasal and nasopharyngeal cancers among U.S. men aged 30 to 60. Am J Ind Med. 2000;37(5):532-541.

60. Vaughan TL, Stewart PA, Teschke K, et al. Occupational exposure to formaldehyde and wood dust and nasopharyngeal cancer. Occup Environ Med. 2000;57(6):376-384.

61. Ho CK, Lo WC, Huang PH, Wu WT, Christiani DC, Lin CT. Suspected nasopharyngeal carcinoma in three workers with long term exposure to sulphuric acid vapour. Occup Environ Med. 1999;56(6):426-428.

62. Golovleva I, Birgander R, Sjalander A, Lundgren E, Beckman L. Interferon-alpha and p53 alleles involved in nasopharyngeal carcinoma. Carcinogenesis. 1997;18(4):645-647.

63. Kongruttanachok N, Sukdikul S, Setavarin S, et al. Cytochrome P450 2E1 polymorphism and nasopharyngeal carcinoma development in Thailand: a correlative study. BMC Cancer. 2001;1:4.
64. Ford JG, Li Y, O’Sullivan MM, et al. Glutathione S-transferase M1 polymorphism and lung cancer risk in African-Americans. Carcinogenesis. 2000;21(11):1971-1975.

65. Gao Y, Zhang Q. Polymorphisms of the GSTM1 and CYP2D6 genes associated with susceptibility to lung cancer in Chinese. Mutat Res. 1999;444(2):441-449.

66. Kiyohara C, Shirakawa T, Hopkin JM. Genetic polymorphism of enzymes involved in xenobiotic metabolism and the risk of lung cancer. Environ Health Prev Med. 2002;7(2):47-59.

67. Strange RC, Jones PW, Fryer AA. Glutathione S-transferase: genetics and role in toxicology. Toxicol Lett. 2000;112-113:357-363.

68. Scully C, Field JK, Tanzawa H. Genetic aberrations in oral or head and neck squamous cell carcinoma (SCCHN): 1. Carcinogen metabolism, DNA repair and cell cycle control. Oral Oncol. 2000;36(3):256-263.
OncoTargets and Therapy

\section{Publish your work in this journal}

OncoTargets and Therapy is an international, peer-reviewed, open access journal focusing on the pathological basis of all cancers, potential targets for therapy and treatment protocols employed to improve the management of cancer patients. The journal also focuses on the impact of management programs and new therapeutic agents and protocols on

\section{Dovepress}

patient perspectives such as quality of life, adherence and satisfaction. The manuscript management system is completely online and includes a very quick and fair peer-review system, which is all easy to use. Visit http://www.dovepress.com/testimonials.php to read real quotes from published authors. 